\title{
INDUCTION OF UNSCHEDULED DNA SYNTHESIS IN HAIRLESS MOUSE EPIDERMIS BY 8-METHOXYPSORALEN PLUS ULTRAVIOLET A (PUVA)
}

\author{
Masaaki MORI $^{1}$, Hiroshi KOBAYASHI ${ }^{2}$, Yoshio KATSUMURA ${ }^{2}$ and Chie FURIHATA ${ }^{3}$ \\ ${ }^{I}$ Life Science Research Center, Shiseido Co., Ltd., \\ 2-12-1 Fukuura, Kanazawa-ku, Yokohama-shi, Kanagawa 236-8643, Japan \\ ${ }^{2}$ Life Science Research Center, Shiseido Co., Ltd., \\ 2-2-1 Hayabuchi, Tsuzuki-ku, Yokohama-shi, Kanagawa 224-8558, Japan \\ ${ }^{3}$ College of Science and Engineering, Aoyama-Gakuin University, \\ 1-1 Morinosatoaoyama, Atsugi-shi, Kanagawa 243-0123, Japan
}

(Received March 22, 2000; Accepted October 20, 2000)

\begin{abstract}
Induction of unscheduled DNA synthesis (UDS) by 8-methoxypsoralen (8-MOP) plus ultraviolet A (UV-A) (PUVA) was investigated in the epidermis of female hairless mice by means of an in vivo - in vitro assay using a liquid scintillation counting method. Groups of three to five 8-week-old female hairless mice had 8-MOP applied once onto two areas of the back after stripping of the stratum corneum with adhesive tape to enhance skin penetration, and were irradiated with UV-A. Skin samples were taken and cultured in a medium containing $\left[{ }^{3} \mathrm{H}\right]$ thymidine with or without hydroxyurea (HU) for 2 $\mathrm{hr}$. DNA of the epidermis was extracted, and the incorporation of $\left[{ }^{3} \mathrm{H}\right]$ thymidine into DNA and the DNA content were determined with a liquid scintillation counter and a fluorescence spectrophotometer, respectively. Induction of UDS was judged in terms of the UDS index [(the ratio of DNA synthesis in the presence of HU to that in its absence) $\times 100]$. In a time-course study, the UDS index was increased at 1, 2 and $24 \mathrm{hr}$ after $1 \times 10^{5} \mathrm{~J} / \mathrm{m}^{2}$ UV-A irradiation with $0.001 \%$ 8-MOP, reaching the maximum level at $24 \mathrm{hr}$. In a dose-response study, it was significantly increased at the dose of $1 \times 10^{5} \mathrm{~J} / \mathrm{m}^{2}$ of UV-A at $24 \mathrm{hr}$ with $0.001 \%$ 8-MOP, but showed no significant change at the doses of $0.5 \times 10^{5}, 2 \times 10^{5}$ and $4 \times 10^{5} \mathrm{~J} / \mathrm{m}^{2}$. In a further study on the effect of varying the dose of 8-MOP, the UDS index was significantly increased at 0.001 and $0.002 \% 8$-MOP at $24 \mathrm{hr}$ after $1 \times 10^{5} \mathrm{~J} / \mathrm{m}^{2} \mathrm{UV}$-A irradiation, reaching the maximum level with $0.002 \% 8$-MOP. The increase of the UDS index in these studies was less than 3 -fold. These results show that PUVA causes a small induction of UDS, which might be due to slow DNA excision repair over a long period.
\end{abstract}

KEY WORDS: Unscheduled DNA synthesis, Replicative DNA synthesis, Hairless mouse epidermis, 8-Methoxypsoralen, Ultraviolet light, PUVA

\section{INTRODUCTION}

A combination of 8-methoxypsoralen (8-MOP) and ultraviolet A (UV-A) radiation, commonly referred to as PUVA, is known to inhibit cell proliferation, and this inhibitory effect is widely utilized for the treatment of skin diseases, such as psoriasis, vitiligo and mycoses (Lerner et al., 1953; Parrish et al., 1974; Gilchrest et al., 1976). Despite the widespread use, epidemiological studies have suggested that PUVA treatment might increase the risk of cutaneous squamous cell carcinoma in humans (Stern et al., 1988; Lindelöf et al., 1991). In rodents, carcinogenicity of PUVA to the skin has been established by oral administration (p.o.), intraperitoneal administration (i.p.) or dermal application of 8-MOP in combination with ultraviolet A radiation. (Griffin,

Correspondence : Masaaki MORI

Vol. 26 No. 1 
1959; Dubertret et al., 1979; Hannuksela et al., 1986). PUVA is also mutagenic, and can cause reverse mutations in bacteria (Dean et al., 1991; Chételat et al., 1993a) and yeast (Chételat et al., 1993a), as well as chromosomal aberrations (Dean et al., 1991; Chételat et al., 1993b), micronucleus induction (Kersten et al., 1999), sister chromatid exchanges (Loveday and Donahue, 1984) and gene mutations (Cristofolini et al., 1990) in cultured mammalian cells.

Unscheduled DNA synthesis (UDS) reflects the genotoxicity of carcinogens and is one measure of the rate of DNA repair. Consequently, detection of UDS is utilized as a technique of mutagenicity testing. Several investigators have tried to detect induction of UDS by PUVA in vitro, in vivo and in vivo - in vitro. Baden et al. (1972) and Kaye et al. (1980) reported induction of UDS by PUVA in human fibroblasts in vitro by liquid scintillation counting and autoradiography, and by liquid scintillation counting, respectively. On the other hand, induction of UDS by PUVA has never been detected in vivo or in vivo - in vitro. Epstein and Fukuyama (1975) failed to demonstrate induction of UDS by PUVA in hairless mouse epidermis in vivo by autoradiography. Hönigsmann et al. (1981) failed to detect induction of UDS by PUVA in healthy human epidermis in vivo - in vitro by autoradiography. Bioulac et al. (1980), and Bishop and Abel (1985) also found no induction of UDS by PUVA in skin from psoriatic patients in vivo - in vitro by autoradiography. We recently reported induction of UDS by skin carcinogens (Mori et al., 1999) and UV irradiation (Mori et al., 2000a), and we also evaluated age-related changes of DNA repair capacity in the epidermis of hairless mice by assaying induction of UDS after UV-B irradiation (Mori et al., 2000b), using a modification of the in vivo - in vitro liquid scintillation counting methods which had been developed for UDS studies in the glandular stomach, forestomach, colon and liver of rats (Furihata et al., 1984, 1985; Furihata and Matsushima, 1987; Sawada et al., 1989; Ohsawa et al., 1993; Furihata and Matsushima, 1995). The feature of this method, as modified for the epidermis, is the evaluation of UDS induction in terms of the UDS index. The use of the UDS index is effective for the detection of UDS induction under conditions where total DNA synthesis (TDS) is reduced owing to inhibition of cell proliferation. The UDS index is calculated after simultaneous measurements of DNA synthesis in the presence and absence of hydroxyurea (HU), which is an inhibitor of replicative DNA synthesis (RDS) (Adams and Lindsay, 1967). In the present study, we examined whether our in vivo - in vitro liquid scintillation counting method is able to detect induction of UDS by PUVA in hairless mouse epidermis. A UV-absorbing glass filter was used in order to eliminate wavelengths below $320 \mathrm{~nm}$. We first tried to find the optimal induction time of UDS after PUVA in a time-course study, and then examined the optimal UV-A dose in a dose-response study. Under the conditions thus identified, we investigated the optimal dose of 8-MOP. The induction of UDS by PUVA in vivo - in vitro was then evaluated under the optimal conditions.

\section{MATERIALS AND METHODS}

\section{Chemicals}

8-MOP (CAS No. 298-81-7) was obtained from Aldrich Chemical Co. (Milwaukee, WI). [ $\left.\mathrm{CH}_{3}{ }^{3} \mathrm{H}\right]$ Thymidine $\left(\left[{ }^{3} \mathrm{H}\right] \mathrm{dThd}, 78 \mathrm{Ci} / \mathrm{mmol}(2.90 \mathrm{TBq} / \mathrm{mmole})\right)$ was from ICN Radiochemicals (Irvine, CA).

\section{Ultraviolet radiation sources}

Fourteen fluorescent tubes, which emit at 300-440 nm (FL32S·BL/DMR lamp, Toshiba Light and Technology, Tokyo), were used. The incident light was passed through a 3-mm-thick ultraviolet absorbing glass filter (Longpass filter WG 335, Schott, Mainz, Germany) to eliminate wavelengths below $320 \mathrm{~nm}$. The output intensity was $4.90 \mathrm{~mW} / \mathrm{cm}^{2}$. These fluorescent tubes were fitted on a medical ultraviolet irradiation apparatus (Dermaray M-DMR-100, Eisai Co., Tokyo), and ultraviolet intensities were measured using a UVradiometer (UVR-305/365-D, Eisai Co., Tokyo).

\section{Animals and treatments}

Female 8-week-old hairless mice (HOS:HR-1, Hoshino Co., Saitama, Japan) were allowed food and water ad libitum until termination of the experiment and were housed in an air-conditioned room with a 12 $\mathrm{hr}$ light/12 hr dark cycle. To ensure sufficient penetration of 8-MOP into the epidermis, tape-stripping treatments were given five times with five $24 \mathrm{~mm} \times 100$ $\mathrm{mm}$ pieces of cellulose tape (Nichiban Co., Cat. No. LP-24, Tokyo, Japan) within $30 \mathrm{sec}$ on the dorsal region. 8-MOP dissolved in acetone was applied once onto two areas (upper and lower back) by using a ring with a diameter of $15 \mathrm{~mm}$ (Nakanishi Company, Inc., Cat. No. Hatome 30, Tokyo, Japan), then mice were placed under the medical ultraviolet irradiation apparatus, and irradiated with UV-A. Animal experiments were conducted in accordance with the guidelines for animal experimentation of the National Institute of 
Unscheduled DNA synthesis in mouse epidermis with PUVA.

Health. The experimental protocol of this study was approved by the institutional review board of the Shiseido Research Center for Animal Welfare.

\section{Preparation of epidermal extracts}

Preparation of epidermal extracts was performed as described previously (Mori et al., 1999, 2000a). Mice underwent euthanasia at the indicated times after irradiation. Two skin pieces of approximately $177 \mathrm{~mm}^{2}$ from the skin to which 8-MOP and subsequent UV-A had been applied were taken and the subcutis was removed. Each portion was cut into halves, and halves from the upper back portion and the lower back portion were paired. These samples were cultured in $3 \mathrm{ml}$ of L15 medium containing $100 \mu \mathrm{g} / \mathrm{ml}$ streptomycin, 100 units/ml penicillin $\mathrm{G}$ and $370 \mathrm{kBq}\left[{ }^{3} \mathrm{H}\right] \mathrm{dThd} / \mathrm{ml}$ with or without $10 \mathrm{mM} \mathrm{HU}$, at $37^{\circ} \mathrm{C}$ for $2 \mathrm{hr}$ in L-shaped glass tubes with gentle shaking (60 oscillations/min). The tissue was washed with $3 \mathrm{ml}$ of L-15 medium containing $100 \mu \mathrm{g} / \mathrm{ml}$ streptomycin and $100 \mathrm{units} / \mathrm{ml}$ penicillin $\mathrm{G}$, and then incubated at $37^{\circ} \mathrm{C}$ for $30 \mathrm{~min}$ in $3 \mathrm{ml}$ of phosphate-buffered saline containing $1 \mathrm{mM}$ unlabeled dThd, and $500 \mathrm{mM}$ ammonium thiocyanate (Hatao et al., 1993) to isolate the epidermis from each sample. The sample was then washed with $3 \mathrm{ml}$ of phosphatebuffered saline, and the epidermis was separated with tweezers. The epidermis was homogenized in $1 \mathrm{ml}$ of $0.5 \%$ sodium dodecylsulfate containing $300 \mathrm{mM}$ sodium chloride and $30 \mathrm{mM}$ tetrasodium ethylenediaminetetraacetate. The homogenate was acidified with $150 \mu 1$ of $70 \%$ trichloroacetic acid, and the precipitate was washed with $1 \mathrm{ml}$ of $10 \%$ trichloroacetic acid, homogenized in $1 \mathrm{ml}$ of $1 \mathrm{~N}$ potassium hydroxide, and incubated at $37^{\circ} \mathrm{C}$ overnight to hydrolyze RNA. On the next day, the supernatant was neutralized with $200 \mu 1$ of $5 \mathrm{~N}$ hydrochloric acid, and DNA and protein were precipitated with $60 \mu 1$ of $70 \%$ trichloroacetic acid. The precipitate was homogenized in $700 \mu 1$ of $5 \%$ trichloroacetic acid and incubated at $80^{\circ} \mathrm{C}$ for $30 \mathrm{~min}$ to hydrolyze DNA. The DNA fraction was obtained as the supernatant after centrifugation at 3,000 rpm for $10 \mathrm{~min}$.

\section{Measurements of DNA synthesis}

DNA synthesis was measured as described previously (Mori et al., 1999, 2000a). Aliquots of 500 1 of the supernatant with $\mathrm{HU}$ and $100 \mu 1$ of that without $\mathrm{HU}$ were dissolved in $3 \mathrm{ml}$ and $1 \mathrm{ml}$ of ACS II scintillant (Amersham Corp., Arlington Heights, IL), respectively, and incorporation of $\left[{ }^{3} \mathrm{H}\right] \mathrm{dThd}$ into DNA was determined with a liquid scintillation counter. The DNA content of the supernatant was determined by using a fluorescence spectrophotometer as described previously (Furihata et al., 1985). Aliquots of $50 \mu 1$ of the supernatant were incubated with $100 \mu 1$ of 2 M 3,5diaminobenzoic acid dihydrochloride (Tokyo Kasei Kogyo Co., Tokyo, Japan) at $37^{\circ} \mathrm{C}$ for $30 \mathrm{~min}$ and 600 $\mu 1$ of $0.6 \mathrm{~N}$ perchloric acid was added. The fluorescence of the mixture was then determined at excitation and emission wavelengths of $410 \mathrm{~nm}$ and $510 \mathrm{~nm}$, respectively. Calf thymus DNA (Sigma Chemical Co., St. Louis, MO) was used as a standard.

\section{Calculations of the UDS index}

The UDS index was calculated as described previously (Mori et al., 1999). It was expressed as the ratio $(\times 100)$ of the amount of DNA synthesis in the presence of HU to that in its absence.

UDS index $=\{[\mathrm{DS}(+\mathrm{HU})] /[\mathrm{DS}(-\mathrm{HU})]\} \times 100$

[DS $(+\mathrm{HU})]$ and $[\mathrm{DS}(-\mathrm{HU})]$ mean the observed DNA synthesis in the presence and in the absence of $\mathrm{HU}$, respectively.

\section{Statistical analysis}

All data were expressed as the mean \pm standard error (S.E.). Statistical significance was determined by the use of Student's $t$ (Welch) test (Gad and Weil, 1982).

\section{RESULTS}

\section{Time-course of UDS induction by PUVA}

DNA synthesis in the presence of HU was not significantly changed at 1,2, 4 and $24 \mathrm{hr}$ after $1 \times 10^{5} \mathrm{~J} / \mathrm{m}^{2}$ UV-A irradiation with $0.001 \%$ 8-MOP application compared to the control acetone application (Fig. 1A), and DNA synthesis in the absence of $\mathrm{HU}$ was significantly decreased at 1 and $2 \mathrm{hr}$ (Fig. 1B). The UDS index was significantly increased at 1,2 and $24 \mathrm{hr}$, showing a maximal 2.9-fold increase at $24 \mathrm{hr}$ (Fig. 1C), while it showed no change in the case of control acetone application. Subsequent studies were assayed at 24 hr after irradiation.

\section{UV-A dose-related response of UDS induction by PUVA}

DNA synthesis in the presence of HU was unchanged after $0.5 \times 10^{5}, 1 \times 10^{5}, 2 \times 10^{5}$ and $4 \times 10^{5}$ $\mathrm{J} / \mathrm{m}^{2} \mathrm{UV}$-A irradiation at $24 \mathrm{hr}$ with $0.001 \%$ 8-MOP application compared to the control acetone application (Fig. 2A), and DNA synthesis in the absence of HU 
was significantly decreased after $1 \times 10^{5}$ and $4 \times 10^{5}$ $\mathrm{J} / \mathrm{m}^{2}$ UV-A irradiation (Fig. 2B). The UDS index was significantly increased after $1 \times 10^{5} \mathrm{~J} / \mathrm{m}^{2} \mathrm{UV}-\mathrm{A}$ irradiation, showing a 2.2-fold increase (Fig. 2C), while it showed no change in the case of control acetone application. For the subsequent 8-MOP dose-related study, the dose of $1 \times 10^{5} \mathrm{~J} / \mathrm{m}^{2}$ of UV-A irradiation was chosen.

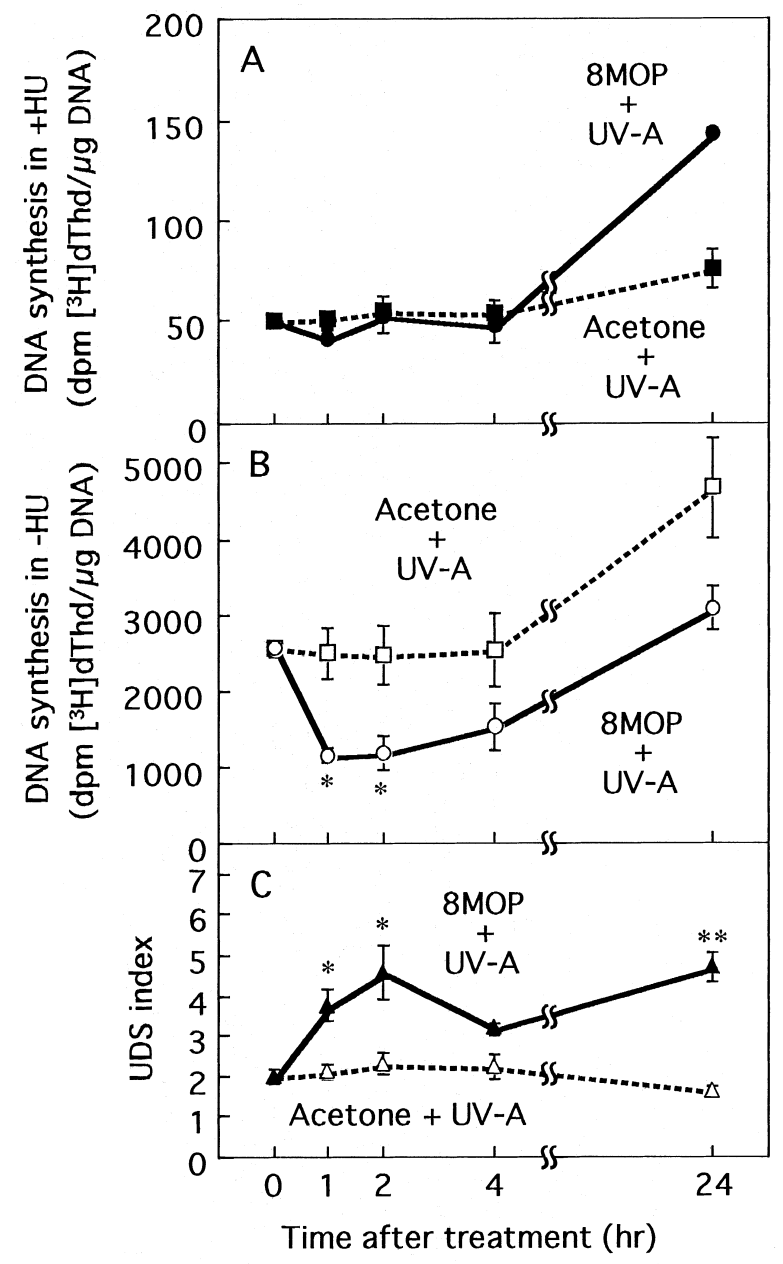

Fig. 1. Time-course of UDS induction by PUVA. The skins were obtained at the indicated times after $1 \times 10^{5} \mathrm{~J} / \mathrm{m}^{2} \mathrm{UV}-\mathrm{A}$ irradiation with acetone or $0.001 \%$ 8-MOP application. Fig. A, B and C show DNA synthesis in the presence and absence of HU, and the UDS index. Values are the meant S.E. for groups of three mice. Asterisks indicate a significant difference from the control group at each time; $* \mathrm{p}<0.05, * * \mathrm{p}<0.01$.

\section{8-MOP dose-related response of UDS induction by PUVA}

DNA synthesis in the presence of HU was unchanged at $0.0005,0.001$ and $0.002 \%$ 8-MOP application at $24 \mathrm{hr}$ after $1 \times 10^{5} \mathrm{~J} / \mathrm{m}^{2} \mathrm{UV}-\mathrm{A}$ irradiation compared to the control acetone application (Fig. 3A), and DNA synthesis in the absence of HU was significantly decreased at 0.001 and $0.002 \%$ 8-MOP application (Fig. 3B). Thus, the UDS index was increased over this dose range, showing a 2.4-fold increase at $0.002 \%$ (Fig.

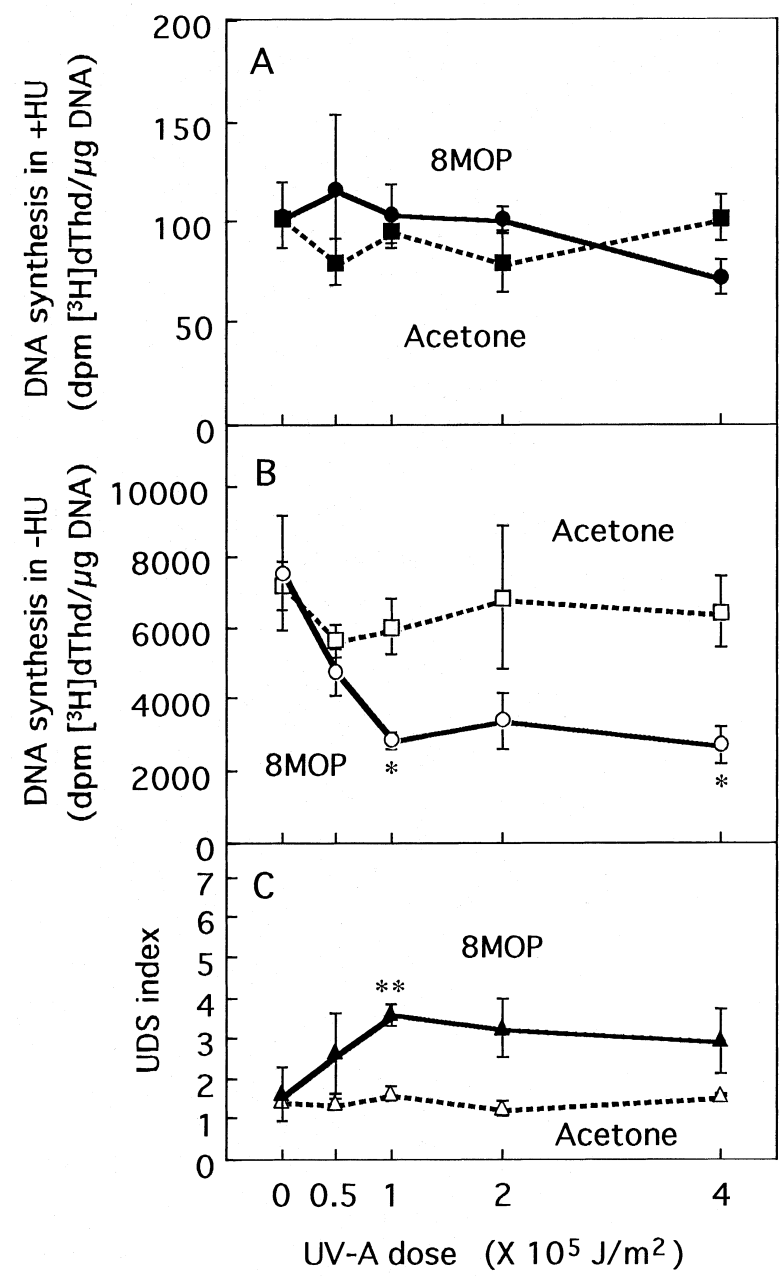

Fig. 2. UV-A dose-related response of UDS induction by PUVA. The skins were obtained at $24 \mathrm{hr}$ after UV$\mathrm{A}$ irradiation with acetone or $0.001 \%$ 8-MOP application. Fig. A, B and C show DNA synthesis in the presence and absence of HU, and the UDS index. Values are the mean \pm S.E. for groups of three mice. Asterisks indicate a significant difference from the control group at each UV-A dose; $* \mathrm{p}<0.05, * * \mathrm{p}<0.01$. 
Unscheduled DNA synthesis in mouse epidermis with PUVA.

3C). Neither $0.001 \%$ 8-MOP application in the absence of UV-A nor UV-A irradiation without 8-MOP caused any change (compared to acetone application in the absence of UV-A) in the DNA synthesis in the presence or absence of HU, or in the UDS index.

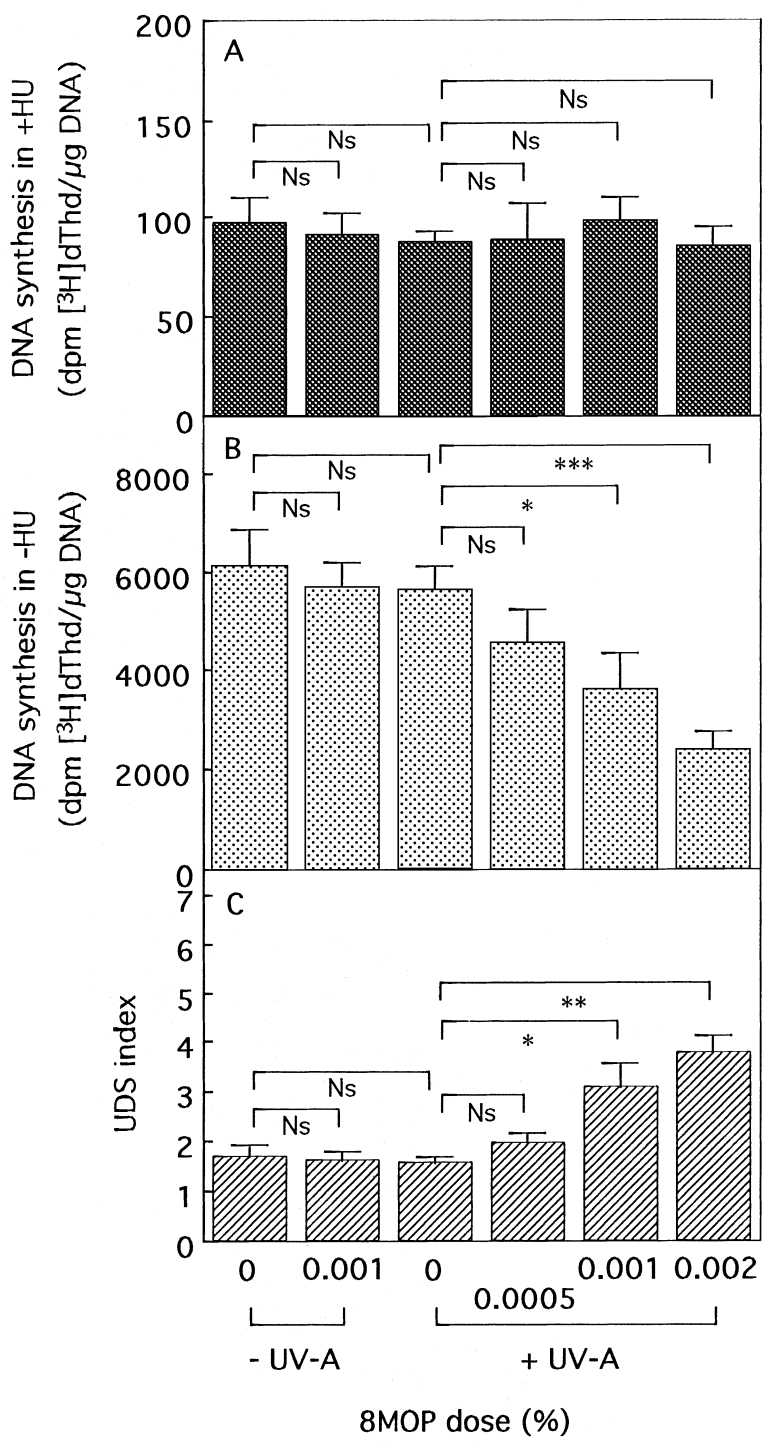

Fig. 3. 8-MOP dose-related response of UDS induction by PUVA. The skins were obtained at $24 \mathrm{hr}$ after $1 \times 10^{5} \mathrm{~J} / \mathrm{m}^{2} \mathrm{UV}-\mathrm{A}$ non-irradiation or irradiation with acetone or 8-MOP. Fig. A, B and $\mathrm{C}$ show DNA synthesis in the presence and absence of HU, and the UDS index. Values are the mean \pm S.E. for groups of five mice. 'Ns's and asterisks indicate no significant difference and a significant difference, respectively, between the indicated groups; ${ }^{\mathrm{Ns}} \mathrm{p} \geqq 0.05, * \mathrm{p}<0.05,{ }^{*} \mathrm{p}<0.01, * * * \mathrm{p}<0.001$.

\section{DISCUSSION}

We were able to detect induction of UDS by PUVA in the epidermis in vivo - in vitro by using our method. However, the increase of the UDS index was less than 3-fold. Thus, the induction of UDS by PUVA was far smaller than that by 4-nitroquinoline 1-oxide (4NQO), $N$-methyl- $N$ '-nitro- $N$-nitrosoguanidine (MNNG) or UV-B irradiation (Mori et al., 1999, 2000a). In studies in vivo or in vivo - in vitro by an autoradiographic method, previous investigators have failed to detect induction of UDS (Epstein and Fukuyama, 1975; Bioulac et al., 1980; Hönigsmann et al., 1981; Bishop and Abel, 1985). Our success in the detection of UDS induction in vivo - in vitro in the present study might have been due to the carefully designed experimental procedures that we employed. For example, we used a UV-absorbing glass filter in order to eliminate the wavelength range of UV-B. In other studies, a UV-absorbing glass filter was not used (Bioulac et al., 1980), or a plate glass with a low UV-absorbing effect was used (Bishop and Abel, 1985). The presence of UV-B would increase the control level of DNA synthesis, and thereby mask slight induction of UDS by PUVA. The specific activity of radiolabeled dThd is also an important factor. We used radiolabeled dThd with a high specific activity of $78 \mathrm{Ci} / \mathrm{mmol}$, whereas in the four studies that failed to detect induction of UDS, the specific activity of the radiolabeled dThd was in the range from 5 to $25 \mathrm{Ci} / \mathrm{mmol}$. The use of radiolabeled dThd with low specific activity would lead to difficulties in sensitive detection of UDS induction. In addition, we first performed a time-course study, and then a dose-response study for UV-A to find optimal conditions for induction of UDS, and confirmed an 8-MOP dose-related response in a subsequent dose-response study. None of the other groups employed such methodology. The use of appropriate experimental conditions is critical for the detection of low levels of UDS induction.

The evaluation of UDS induction in terms of the UDS index was one of the key points in the detection of UDS induction by PUVA. In general, it is difficult to detect a small amount of UDS in the skin with liquid scintillation counting, because induction of UDS in the skin is accompanied by a decrease of TDS (Mori et al., 1999, 2000a, 2000b). PUVA caused a clear decrease of TDS. The calculation of the UDS index allows the detection of UDS induction under such conditions. We previously reported the relationship between the change of DNA synthesis and induction of UDS in 
M. MORI et al.

dose-response studies (Mori et al., 1999). We concluded that i) parallel changes of DNA synthesis in the presence and absence of HU while maintaining a UDS index of approximately two is indicative of non-induction of UDS; ii) cases in which DNA synthesis in the presence of $\mathrm{HU}$ was increased and that in its absence was decreased were regarded as clear induction of UDS, and in this case, the UDS index is greatly increased; iii) when DNA synthesis in the presence of HU was unchanged and that in its absence was decreased, this was also regarded as indicating induction of UDS; in such a case, the UDS index shows a small increase. The changes of DNA synthesis in the presence and absence of HU in PUVA came under the last category, indicating slight induction of UDS by PUVA.

We administered 8-MOP by topical application subsequent to tape-stripping, before UV-A irradiation. We did not try other administration routes, such as p.o. and i.p., because the carcinogenicity of 8-MOP orally administered in PUVA seems to be far lower than that after topical application (Griffin, 1959; Langner et al., 1977), and i.p. administration has not been used for humans.

In the time-course study (Fig. 1), the control acetone application increased DNA synthesis in the presence and absence of $\mathrm{HU}$ at $24 \mathrm{hr}$ after UV-A irradiation. This reflected the cell proliferation after the tapestripping treatments. However, since the control acetone application did not produce an increase of the UDS index at $24 \mathrm{hr}$, we were able to assay induction of UDS by PUVA at this time point. Induction of UDS by PUVA was observed throughout the period, except at 4 hr. This implies that DNA excision repair takes place gradually over a long period. Reduction of UDS at $4 \mathrm{hr}$ might be explained in terms of excision repair capacity of epidermal cells for two types of photoadducts between 8-MOP and DNA, i.e., monoadducts and cross-links. Either the 3,4-double bond in the pyrone ring or the 4', 5' -double bond in the furan ring of 8MOP photoreacts with the 5',6'-double bond of the pyrimidine in DNA in the presence of UV-A, producing 3,4-cyclobutane monoadducts or 4',5'-cyclobutane monoadducts, respectively. Further photoreaction of these monoadducts leads to further ring formation with another nearby pyrimidine on the opposite DNA strand, and results in the formation of diadducts, i.e., crosslinks (Musajo et al., 1967a, 1967b; Dall'Acqua et al., 1970). Stern (1989) noted that repair response to 8MOP in human fibroblasts primarily involves the removal of monoadducts, and cross-links appear to per- sist. Chandra et al. (1974) investigated the removal of adducts in guinea pig skin using radiolabeled psoralen, which is an analogue of 8-MOP, and confirmed that monoadducts are more easily removed from DNA than cross-links. Thus, since the removal rates of monoadducts and cross-links differ from each other, it seems natural that the pattern of UDS induction should be biphasic. Reduction of UDS at $4 \mathrm{hr}$ might correspond to completion of excision of monoadducts, and reinduction of UDS at $24 \mathrm{hr}$ might reflect removal of cross-links.

In the UV-A dose-response study (Fig. 2), induction of UDS was not observed at the doses of $2 \times 10^{5}$ and $4 \times 10^{5} \mathrm{~J} / \mathrm{m}^{2}$, though the dose of $1 \times 10^{5} \mathrm{~J} / \mathrm{m}^{2}$ induced UDS. Prolonged UV-A irradiation is said to convert monoadducts into cross-links (Dall'Acqua et al., 1970), and, according to Seki et al. (1978), crosslinks are responsible for lethal effects rather than mutation induction. The lack of induction of UDS at the doses of $2 \times 10^{5}$ and $4 \times 10^{5} \mathrm{~J} / \mathrm{m}^{2}$ might reflect further cross-link formation and a decrease of excision repair capacity owing to an increase of lethal action.

In the 8-MOP dose-response study (Fig. 3), induction of UDS by PUVA was small. The pattern of DNA synthesis in the presence and absence of $\mathrm{HU}$, and the change of UDS index by PUVA were similar to those in response to diepoxybutane (DEB), 7,12-dimethylbenz[a]anthracene (DMBA) and benzo[a]pyrene (B[a]P) in a previous study (Mori et al., 1999). Kleinau et al. (1997) reported that UV-B accelerates the 8-MOP adduct repair process, and the repair of thymine dimers and 8-MOP adducts together is probably easier and faster to perform than the repair of monoadducts and cross-links generated by PUVA. Their result suggests that the use of a solar simulator, which emits not only UV-A but also UV-B, might increase UDS more than the use of UV-A. Further studies of the effects of various lamps and other photomutagens on the induction of UDS should contribute to the establishment of the photo-UDS assay as a test method to detect photomutagenic or photocarcinogenic chemicals.

\section{ACKNOWLEDGMENT}

The authors are grateful to Dr. W.R.S. Steele for his critical reading of the manuscript.

\section{REFERENCES}

Adams, R.L.P. and Lindsay, J.G. (1967): Hydroxyurea, reversal of inhibition and use as a cell-synchroniz- 
Unscheduled DNA synthesis in mouse epidermis with PUVA.

ing agent. J. Biol. Chem., 242, 1314-1317.

Baden, H.P., Parrington, J.M., Delhanty, J.D.A. and Pathak, M.A. (1972): DNA synthesis in normal and xeroderma pigmentosum fibroblasts following treatment with 8-methoxypsoralen and long wave ultraviolet light. Biochim. Biophys. Acta, 262, 247-255.

Bioulac, P., Denechaud, M., Dubuisson, L., Doutre, M.S., Ducassou, D. and Beylot, C. (1980): Unscheduled DNA synthesis in psoriatic skin after ultraviolet irradiation and the effects of a combined treatment with 8-methoxypsoralen and longwave ultraviolet radiation: A clinical study. Br. J. Dermatol., 102, 285-295.

Bishop, S.C. and Abel, E.A. (1985): DNA repair elicited by UVB during PUVA therapy for psoriasis. Arch. Dermatol. Res., 278, 25-30.

Chandra, P., Dall'Acqua, F., Marciani, S. and Rodighiero, G. (1974): Studies on the repair of DNA photodamaged by furocoumarins. In Sunlight and Man (Fitzpatrick, T.B., Pathak, M.A., Harber, L.C., Seiji, M. and Kukita, A., eds.), pp. 411-417, University of Tokyo Press, Tokyo.

Chételat, A., Albertini, S., Dresp, J.H., Strobel, R. and Gocke, E. (1993a): Photomutagenesis test development: I. 8-Methoxypsoralen, chlorpromazine and sunscreen compounds in bacterial and yeast assays. Mutat. Res., 292, 241-250.

Chételat, A., Dresp, J.H. and Gocke, E. (1993b): Photomutagenesis test development: II. 8-Methoxypsoralen, chlorpromazine and sunscreen compounds in chromosomal aberration assays using CHO cells. Mutat. Res., 292, 251-258.

Cristofolini, M., Recchia, G., Boi, S., Piscioli, F., Bordin, F., Baccichetti, F., Carlassare, F., Tamaro, M., Pani, B., Babudri, N., Guiotto, A., Rodighiero, P., Vedaldi, D. and Dall'Acqua, F. (1990): 6Methylangelicins: New monofunctional photochemotherapeutic agents for psoriasis. Br. J. Dermatol., 122, 513-524.

Dall' Acqua, F., Marciani, S. and Rodighiero, G. (1970): Inter-strand cross-linkages occurring in the photoreaction between psoralen and DNA. FEBS Lett., 9, 121-123.

Dean, S.W., Lane, M., Dunmore, R.H., Ruddock, S.P., Martin, C.N., Kirkland, D.J. and Loprieno, N. (1991): Development of assays for the detection of photomutagenicity of chemicals during exposure to UV light-I. Assay development. Mutagenesis, 6, 335-341.
Dubertret, L., Averbeck, D., Zajdela, F., Bisagni, E., Moustacchi, E., Touraine, R. and Latarjet, R. (1979): Photochemotherapy (PUVA) of psoriasis using 3-carbethoxypsoralen, a non-carcinogenic compound in mice. Br. J. Dermatol., 101, 379389.

Epstein, J.H. and Fukuyama, K. (1975): Effects of 8methoxypsoralen-induced phototoxic effects on mammalian epidermal macromolecule synthesis in vivo. Photochem. Photobiol., 21, 325-330.

Furihata, C., Yamawaki, Y., Jin, S.-S., Moriya, H., Kodama, K., Matsushima, T., Ishikawa, T., Takayama, S. and Nakadate, M. (1984): Induction of unscheduled DNA synthesis in rat stomach mucosa by glandular stomach carcinogens. J. Natl. Cancer Inst., 72, 1327-1334.

Furihata, C., Yoshida, S. and Matsushima, T. (1985): Potential initiating and promoting activities of diacetyl and glyoxal in rat stomach mucosa. Jpn. J. Cancer Res. (Gann), 76, 809-814.

Furihata, C. and Matsushima, T. (1987): Use of in vivo/in vitro unscheduled DNA synthesis for identification of organ-specific carcinogens. CRC Crit. Rev. Toxicol., 17, 245-277.

Furihata, C. and Matsushima, T. (1995): In vivo shortterm assays for tumor initiation and promotion in the glandular stomach of Fischer rats. Mutat. Res., 339, 15-35.

Gad, S.C. and Weil, C.S. (1982): Statistics for toxicologists. In Principles and Methods of Toxicology (Hayes, A.W., ed.), pp. 273-320, Raven Press, New York.

Gilchrest, B.A., Parrish, J.A., Tanenbaum, L., Haynes, H.A. and Fitzpatrick, T.B. (1976): Oral methoxsalen photochemotherapy of mycosis fungoides. Cancer, 38, 683-689.

Griffin, A.C. (1959): Methoxsalen in ultraviolet carcinogenesis in the mouse. J. Invest. Dermatol., 32, 367-372.

Hannuksela, M., Stenbäck, F. and Lahti, A. (1986): The carcinogenic properties of topical PUVA. A lifelong study in mice. Arch. Dermatol. Res., 278, 347-351.

Hatao, M., Mark, R., Stoudemayer, T. and Gabriel, K.L. (1993): Recovery process of Langerhans cells in human skin following ultraviolet B irradiation. J. Toxicol.-Cut. \& Ocular Toxicol., 12, 293301.

Hönigsmann, H., Jaenicke, K.F., Brenner, W., Rauschmeier, W. and Parrish, J.A. (1981): Unscheduled DNA synthesis in normal human 
M. MORI et al.

skin after single and combined doses of UV-A, UV-B and UV-A with methoxsalen (PUVA). Br. J. Dermatol., 105, 491-501.

Kaye, J., Smith, C.A. and Hanawalt, P.C. (1980): DNA repair in human cells containing photoadducts of 8-methoxypsoralen or angelicin. Cancer Res., 40, 696-702.

Kersten, B., Zhang, J., Brendler-Schwaab, S.Y., Kasper, P. and Müller, L. (1999): The application of the micronucleus test in Chinese hamster V79 cells to detect drug-induced photogenotoxicity. Mutat. Res., 445, 55-71.

Kleinau, O., Böhm, F. and Lanto, B. (1997): Different DNA repair time courses in human lymphoid cells after UVA, UVA, UVB and PUVA in vitro. J. Photochem. Photobiol. B: Biol., 41, 103-108.

Langner, A., Wolska, H., Marzulli, F.N., Jablonska, S., Jarzabek-Chorzelska, M., Glinski, W. and Pawinska, M. (1977): Dermal toxicity of 8methoxypsoralen administered (by gavage) to hairless mice irradiated with long-wave ultraviolet light. J. Invest. Dermatol., 69, 451-457.

Lerner, A.B., Denton, C.R. and Fitzpatrick, T.B. (1953): Clinical and experimental studies with 8methoxypsoralen in vitiligo. J. Invest. Dermatol., 20, 299-314.

Lindelöf, B., Sigurgeirsson, B., Tegner, E., Larkö, O., Johannesson, A., Berne, B., Christensen, O.B., Andersson, T., Törngren, M., Molin, L., NylanderLundqvist, E. and Emtestam, L. (1991): PUVA and cancer: A large-scale epidemiological study. Lancet, 338, 91-93.

Loveday, K.S. and Donahue, B.A. (1984): Induction of sister chromatid exchanges and gene mutations in Chinese hamster ovary cells by psoralens. Natl. Cancer Inst. Monogr., 66, 149-155.

Mori, M., Kobayashi, H., Sugiyama, C., Katsumura, Y. and Furihata, C. (1999): Induction of unscheduled DNA synthesis in hairless mouse epidermis by skin carcinogens. J. Toxicol. Sci., 24, 217-226.

Mori, M., Kobayashi, H., Naganuma, M., Sugiyama, C., Katsumura, Y. and Furihata, C. (2000a): Induction of unscheduled DNA synthesis in hairless mouse epidermis by ultraviolet light. J.
Toxicol. Sci., 25, 17-24.

Mori, M., Kobayashi, H., Sugiyama, C., Katsumura, Y. and Furihata, C. (2000b): Effect of aging on unscheduled DNA synthesis induction by UV-B irradiation in hairless mouse epidermis. J. Toxicol. Sci., 25, 181-188.

Musajo, L., Bordin, F., Caporale, G., Marciani, S. and Rigatti, G. (1967a): Photoreactions at $3655 \AA$ between pyrimidine bases and skin-photosensitizing furocoumarins. Photochem. Photobiol., 6, 711-719.

Musajo, L., Bordin, F. and Bevilacqua, R. (1967b): Photoreactions at $3655 \AA$ linking the 3-4 double bond of furocoumarins with pyrimidine bases. Photochem. Photobiol., 6, 927-931.

Ohsawa, K., Furihata, C., Mori, M. and Ikui, E. (1993): Ability of $N$-methyl- $N$ '-nitro- $N$-nitrosoguanidine, 4-nitroquinoline 1-oxide, dimethylnitrosamine, and $\mathrm{NaCl}$ to induce unscheduled DNA synthesis, stimulate replicative DNA synthesis, and produce DNA single-strand breaks in pyloric mucosa of rat stomach. Mutat. Res., 287, 307-319.

Parrish, J.A., Fitzpatrick, T.B., Tanenbaum, L. and Pathak, M.A. (1974): Photochemotherapy of psoriasis with oral methoxsalen and longwave ultraviolet light. N. Engl. J. Med., 291, 1207-1211.

Sawada, S., Furihata, C. and Matsushima, T. (1989): In vivo short-term assays of repair and replication of rat liver DNA. J. Cancer Res. Clin. Oncol., 115, 345-350.

Seki, T., Nozu, K. and Kondo, S. (1978): Differential causes of mutation and killing in Escherichia coli after psoralen plus light treatment: Monoadducts and cross-links. Photochem. Photobiol., 27, 1924.

Stern, R.S., Lange, R. and Members of the Photochemotherapy Follow-up Study (1988): Nonmelanoma skin cancer occurring in patients treated with PUVA five to ten years after first treatment. J. Invest. Dermatol., 91, 120-124.

Stern, R.S. (1989): PUVA and the induction of skin cancer. In Skin tumors: Experimental and Clinical Aspects (Conti, C.J., Slaga, T.J. and Klein-Szanto, A.J.P., eds.), pp. 85-101, Raven Press, New York. 